\title{
Nutritional information: do we know what we are eating?
}

\author{
BY RICHARD MOODY \\ School of Food and Consumer Studies, The Robert Gordon Institute of Technology, \\ Aberdeen $A B 92 P G$
}

The European Economic Community (EEC) has made slow progress towards achieving a unified position on the labelling of foods with nutrition information. The Nutrition Labelling Rules Directive (90/496/EEC) was adopted in September 1990, and will take 5 years to become fully implemented. Nutrition labelling will remain voluntary unless a nutrition claim is made, when detailed declarations must be made in a specified form. A second Directive, which will require selected nutrients to be the subject of compulsory labelling, has support in principle, but the outcome of the current legislative programme will be monitored before these are considered again.

Not only will the information provided about foods become more comprehensive and useful, but the wider range of 'foods' and 'food businesses' now defined under the Food Safety Act 1990 means that all food materials from farm products through to prepacked foods on retail sale will be the subject of new legislation.

It is important for nutritionists to ensure that full and accurate information is available on foods so that consumers can make an informed choice when eating a healthy diet which meets current recommendations (Department of Health, 1991a,b). Though information on foods will be incomplete, because of the current voluntary nature of the law, efforts must still be directed towards the development of information systems which can support all foods sold, both for household use, and foods eaten out. The Food Advisory Committee (FAC) has been asked to review the problem in the latter group which now comprises some $25 \%$ of our food consumption.

In the current stage of legislative control, unless satisfactory systems are available to caterers, the operational problems of providing the required information may well prove to be a major disincentive to food businesses to innovate and widen their range of healthy eating alternatives.

\section{TRENDS IN FOOD PURCHASING AND CONSUMPTION}

It is necessary to examine food consumption patterns in the UK in some detail to identify the sectors which should be equipped with information systems. In addition there may be nutritional reasons for focusing attention on foods consumed in one sector compared with another. Put another way, if foods consumed in one sector were 'less healthy' than in others, then the case for attempting to implement effective information systems in that sector would become stronger in the hope that easy access to relevant information may influence choice.

In a commercial sense, the profitability of an operation should not be impaired by such a development, in fact the opening up of information sources may actually stimulate activity over a diversified product base.

The Annual Report of the National Food Survey Committee for 1989 (Ministry of Agriculture, Fisheries and Food, 1990) shows (Table 1) that half our food expenditure is 
Table 1. Percentage of total consumer's expenditure spent on foods in the UK 1979-89* (from Ministry of Agriculture, Fisheries and Food, 1990)

\begin{tabular}{lrrr}
\hline & 1979 & 1984 & 1989 \\
\hline Household food & $17 \cdot 6$ & $14 \cdot 7$ & $12 \cdot 1$ \\
Meals out & $4 \cdot 2$ & $4 \cdot 2$ & $5 \cdot 7$ \\
Alcoholic drinks & $7 \cdot 3$ & $7 \cdot 2$ & $6 \cdot 2$ \\
Total & $29 \cdot 1$ & $26 \cdot 1$ & $24 \cdot 0$ \\
\hline
\end{tabular}

* Base: $1989100 \%=£ 324348 \times 10^{6}$.

Table 2. Number of meals eaten outside the home (per person per week) in the UK 1987-89 (from Ministry of Agriculture, Fisheries and Food, 1990)

\begin{tabular}{llll}
\hline & 1987 & 1988 & 1989 \\
\hline Mid-day & 1.84 & 1.85 & 1.89 \\
All meals out & 3.54 & 3.69 & 3.84 \\
\hline
\end{tabular}

on foods for home consumption, and also a marked increase in spending on meals eaten out of the home. This jumped from $14.5 \%$ of the food expenditure in 1979 to nearly $24 \%$ in 1989. This increase should be considered within the context of a decline in food expenditure as a proportion of total expenditure from $29 \%$ in 1979 to $24 \%$ in 1989 .

The number of meals eaten outside the home (Table 2) reflects the increased expenditure, particularly those meals consumed other than at mid-day, i.e. evening, which show the greatest increase in popularity. The shift to eating out, to about one-quarter of our food consumption can, therefore, be identified as a significant social development which has major implications for the provision of nutrition information.

\section{DEVELOPMENTS IN CATERING SECTORS}

These patterns of food consumption and expenditure have occurred in parallel with the developments of various catering sectors, particularly those servicing the growing 'eating out' trends. The operational priorities of these sectors must be accommodated if healthy eating and nutritional information is to become an integral part of their customer service.

The scale of the catering sector serving one-quarter of our food consumption has been quantified in Tables 3 and 4.

The 1980s have seen considerable sectoral growth in the number of businesses in the catering industry. Of most importance are restaurants/cafes (by $42 \%$ ), take-aways (by $28 \%$ ), and contract caterers (by $83 \%$ ), while the largest sector, the pubs, have only shown slight increases in number, and hotels have declined in number, both have still increased turnover.

The number of meals eaten out in this analysis (Table 4 ) averages 3.13 which is below the 1989 (Ministry of Agriculture, Fisheries and Food, 1990) estimate of 3.84 for meals eaten outside the home. The definition of a meal in Table 4 as food served on a plate only, does not include snacks and, therefore, probably accounts for most of the difference. 
Table 3. Number of catering businesses (plus in parentheses, turnover in $£ \times 10^{6}$ including value added tax) in the UK 1980-88 (from Central Statistical Office, 1991)

\begin{tabular}{|c|c|c|c|}
\hline Sector & 1980 & 1984 & 1988 \\
\hline All catering & $109471(12424)$ & $117715(17284)$ & $122277(25856)$ \\
\hline Hotels, etc. & $14281 \quad(2483)$ & $12934 \quad(3374)$ & $13649 \quad(5522)$ \\
\hline Holiday camps, etc. & $1587 \quad(405)$ & $1605 \quad(456)$ & $1636 \quad(695)$ \\
\hline Restaurants, cafes & $11512 \quad(1431)$ & $12692 \quad(1900)$ & $16310 \quad(3190)$ \\
\hline Take-aways, etc & $22715 \quad(1103)$ & $29205 \quad$ (1869) & $29118 \quad(3375)$ \\
\hline Pubs & $40608 \quad(4857)$ & $42010 \quad(6888)$ & $42076 \quad(8714)$ \\
\hline Clubs & $17571 \quad(1570)$ & 17786 & $17294 \quad(2387)$ \\
\hline Catering contractors & $1196 \quad(575)$ & 1483 & $2192 \quad(1273)$ \\
\hline
\end{tabular}

Table 4. Total number of meals eaten out per catering sector in the UK 1990 (from Advertising Association, 1991)

\begin{tabular}{|c|c|c|c|}
\hline \multirow[b]{2}{*}{ Sector } & \multicolumn{2}{|c|}{ Total no. of meals } & \multirow{2}{*}{$\begin{array}{c}\text { No. of meals per person } \\
\text { (over } 5 \text { years) }\end{array}$} \\
\hline & $\times 10^{6}$ & $\%$ & \\
\hline \multicolumn{4}{|l|}{ Profit-related } \\
\hline Hotels & 582 & $6 \cdot 7$ & 11 \\
\hline Restaurants & 392 & $4 \cdot 5$ & 7 \\
\hline Pubs & 1340 & $15 \cdot 4$ & 25 \\
\hline Fast food & 419 & $4 \cdot 8$ & 8 \\
\hline Travel & 324 & $3 \cdot 7$ & 6 \\
\hline Cafes/take-aways & 1551 & $17 \cdot 8$ & 29 \\
\hline Clubs/leisure & 743 & $8 \cdot 6$ & 14 \\
\hline Total & 5351 & $61 \cdot 5$ & 100 \\
\hline \multicolumn{4}{|l|}{ Cost-related } \\
\hline Canteens & 1689 & $19 \cdot 4$ & 32 \\
\hline Health care & 550 & $6 \cdot 3$ & 10 \\
\hline Education & 964 & $11 \cdot 1$ & 18 \\
\hline Public services & 146 & $1 \cdot 7$ & 3 \\
\hline Total & 3349 & $38 \cdot 5$ & 63 \\
\hline Total & 8700 & 100 & 163 \\
\hline
\end{tabular}

Table 4 reveals that over $60 \%$ of eating out is in the profit-related sector with pubs, cafes, and take-aways providing over $33 \%$ of the meals. With $38.5 \%$ of meals served in canteens and public sector institutions, the range of commercial environments into which nutrition information transmission must fit, can be clearly seen. Some take-away, fast-food, and chain-restaurant businesses which feature standard dishes are able to utilize poster displays or leaflets at the point of sale to transmit nutrition information, but when an unlimited choice is offered, such a mechanism is unworkable. The challenge in the eating-out sector, where menu choice is featured, is significantly greater than in other sectors, and the operational needs must be fully satisfied if healthy eating is to become a marketing priority in these businesses. 


\section{NUTRITIONAL ASPECTS OF EATING OUT}

It is possible, from the data collected in the annual National Food Survey, to estimate the nutritional quality of foods consumed when eating out, compared with those purchased for consumption in the home. This is shown in Table 5 in relation to the amount of food energy consumed, and in Table 6 in relation to the total nutritional intake. Foods eaten out of the home (Table 5) made a lower relative contribution of protein, fibre, and iron, but more sugars than the diet as a whole.

Nutritionally, the picture is of one-quarter of our food intake providing a less healthy diet than that as a whole, but irrespective of comparisons, a diet which must be significantly improved to meet current healthy eating recommendations (Department of Health, 1991a). The provision of accurate and accessible nutrition information in this context is an important component in any future improvements to our diets.

Table 5. The percentage of food energy from selected nutrients derived from (a) all foods eaten and (b) foods eaten outside the home in UK 1989 (from Office of Population Census and Surveys, 1990)

(Mean values with their standard errors)

\begin{tabular}{|c|c|c|c|c|}
\hline & \multicolumn{2}{|c|}{ (a) All foods eaten } & \multicolumn{2}{|c|}{ (b) Foods eaten out } \\
\hline & Mean & $\mathrm{SE}$ & Mean & $\mathrm{SE}$ \\
\hline \multicolumn{5}{|c|}{$\begin{array}{l}\text { Percentage of total food energy } \\
\text { eaten in (a) or (b) derived from: }\end{array}$} \\
\hline Protein & $15 \cdot 4$ & 0.07 & $13 \cdot 4$ & $0 \cdot 12$ \\
\hline Carbohydrate & $44 \cdot 4$ & 0.12 & $46 \cdot 3$ & $0 \cdot 33$ \\
\hline Total fat & $40 \cdot 4$ & $0 \cdot 11$ & $40 \cdot 9$ & 0.23 \\
\hline \multicolumn{5}{|c|}{$\begin{array}{l}\text { Amount (units) of nutrients per } \\
4.2 \mathrm{MJ}(1000 \mathrm{kcal}) \text { food energy } \\
\text { consumed in (a) or (b): }\end{array}$} \\
\hline Fibre (g) & $11 \cdot 3$ & 0.07 & $8 \cdot 88$ & $0 \cdot 10$ \\
\hline Iron (mg) & $7 \cdot 1$ & $0 \cdot 16$ & $5 \cdot 24$ & 0.06 \\
\hline Sugars $(\mathrm{g})$ & $50 \cdot 8$ & 0.33 & $64 \cdot 1$ & 1.08 \\
\hline
\end{tabular}

Table 6. The percentage of the total intake of selected nutrients derived from eating out (from Office of Population Census and Surveys, 1990)

(Mean values with their standard errors)

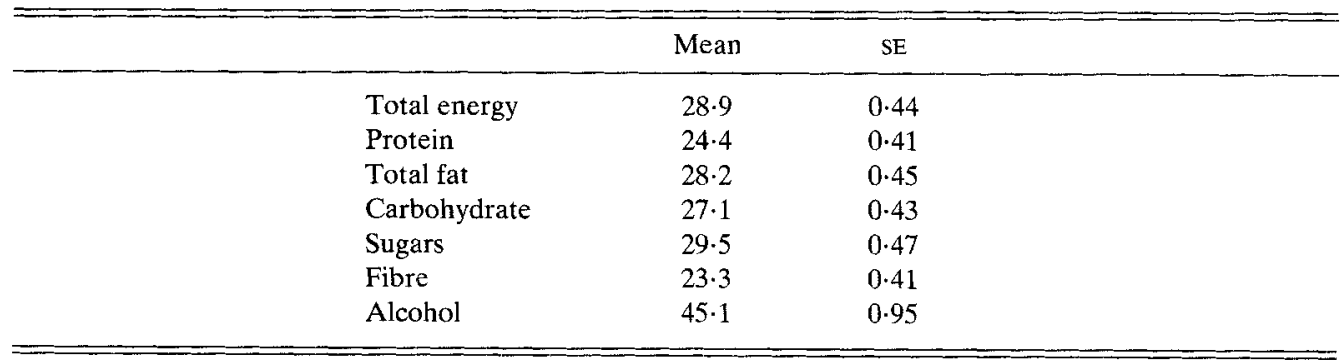


Table 7. The nutrition labelling rules: a summary

\begin{tabular}{|c|c|c|c|}
\hline \multicolumn{2}{|c|}{$\begin{array}{l}\text { 'Trigger' } \\
\text { A claim naming: }\end{array}$} & \multirow{2}{*}{$\begin{array}{l}\begin{array}{l}\text { Nutrients to be } \\
\text { declared }\end{array} \\
\begin{array}{c}\text { Energy, protein, carbohydrate, fat } \\
\text { (group 1) }\end{array}\end{array}$} & \multirow{2}{*}{$\begin{array}{l}\begin{array}{l}\text { Date of } \\
\text { implementation }\end{array} \\
\text { October } 1993\end{array}$} \\
\hline (A) & One or more of: four & & \\
\hline (B) & $\begin{array}{l}\text { One or more of: sugars, saturates, } \\
\text { fibre, sodium (plus four) }\end{array}$ & $\begin{array}{l}\text { Energy, protein, carbohydrate, fat, } \\
\text { plus the named nutrient }\end{array}$ & $\begin{array}{r}\text { October } 1993 \\
\quad(\text { until 1995) }\end{array}$ \\
\hline (C) & $\begin{array}{l}\text { One or more of: sugars, saturates, } \\
\text { fibre, sodium, (plus four) }\end{array}$ & $\begin{array}{l}\text { Energy, protein, carbohydrate, sugars, } \\
\text { fat, saturates, fibre, sodium (group 2) }\end{array}$ & October 1995 \\
\hline (D) & $\begin{array}{l}\text { One or more of: starch, polyols, } \\
\text { mono- and polyunsaturates, } \\
\text { cholesterol plus all vitamins and } \\
\text { minerals in the Appendix to } \\
\text { Directive }\end{array}$ & Named nutrient(s) plus group 2 & October 1993 \\
\hline (E) & $\begin{array}{l}\text { Mono- and polyunsaturates or } \\
\text { cholesterol }\end{array}$ & $\begin{array}{l}\text { Named nutrient, plus saturates } \\
\text { (obligatory after 1995) }\end{array}$ & October 1993 \\
\hline
\end{tabular}

\section{NUTRITION LABELLING REQUIREMENTS}

The new Nutrition Labelling Rules Directive (90/496/EEC) will be implemented through amendments to Food Labelling Regulations by October 1993, with a second phase relating to claims for the 'plus four' nutrients (see Table 7) implemented in 1995. The system will be evaluated in 1998 with a view to implementing a restricted compulsory system of nutritional labelling. The law will apply to foods as delivered to the ultimate consumer, and also to foods for supply to mass caterers.

Labelling will be voluntary, except where a claim (any message or representation relating to nutritional content) is made on labels, in presentations, or advertising, then it is compulsory. There is a restricted list of nutrients about which claims may be made. Table 7 is a composite of the Nutrition Labelling Rules. Exceptions to the requirements for the labelling shown in Table 7 apply if the nutrient is named in a generic context in product titles or in advertising, or if it is named as a requirement of other regulations. The Directive details all presentational procedures, together with conversion factors, units, and recommended dietary amounts.

The recent FAC Review of Food Labelling (Ministry of Agriculture, Fisheries and Food, 1991) proposed that all nutrition information is presented in a standard panel with other essential information. The size and prominence of this panel and the prospect of graphical representations of nutritional composition, are also being considered.

Not surprisingly, recommendations for labelling in the catering sector have not moved forward. The EEC Directive leaves the manner of communication to 'national provisions', whilst the FAC (Ministry of Agriculture, Fisheries and Food, 1991) has been asked by the government (Section 38) to carry out a detailed review of the problem whilst recognizing that a different approach may be needed.

The Food Safety Act 1990 also has a bearing on the application of the labelling 
requirements in that new definitions of key phrases has considerably widened the range of food-related activities controlled by Food Law: 'food' now also includes some live animals/crops, milk and tap water; 'food business' includes any commercial operation in the food chain, regardless of profit-making status; 'sale of food' is not limited to the point of sale and includes any food commonly used for human consumption. There is now virtually no part of the food chain outside the control of the Law and, therefore, if claims are made about foods, the consumer should have access to a comprehensive source of information on which to base his/her decision.

\section{CATEGORIES OF FOODS TO BE LABELLED, IF CLAIM MADE}

1. Wrapped. Foods prepackaged and delivered to the retailer will display a standard panel containing the relevant information.

2. Packed on site for direct sale. The FAC (Ministry of Agriculture, Fisheries and Food, 1991) recommend that the same rules should apply to these foods as to those in category 1. For example, dried fruits or cereals packed for direct sale in a health food shop will need to carry the approved nutritional declarations on the label if any claim is made.

3. Unwrapped. (a) Single foods sold for consumption off the premises: these foods can comprise up to one-third of retail sales, for example fruit, vegetables, delicatessen, morning goods. To allow, for example, 'low-fat' products to be sold, a label with the necessary information would be needed. Hardware to perform this task would not be difficult to develop. In fact 'electronic point of sale' systems could also be modified to provide information on any product identifiable by a bar-code.

(b) Take-away meals for consumption off the premises: at present, point of sale displays in fast-food units are a major source of nutritional information in this sector, although such a system is only viable when very standardized portion control and restricted choices are operated; but as such units provide less than one-third (Table 4) of the meals served in this sector, there is still much scope for removing disincentives to developing healthy eating alternatives in the remainder.

(c) Meals for immediate consumption on the premises: the major component in the eating-out sector (Table 4). The problems associated with the marketing of meals which carry a nutritional claim are mainly accuracy (are portion sizes standardized enough to give accurate average data?) and speed (will the process interrupt or delay food ordering and thereby limit potential turnover?). The marketing advantages associated with an extended product range will not be underestimated by progressive food businesses.

\section{COMPUTERIZED NUTRITION INFORMATION SYSTEMS}

To provide quick feedback on menu choice to a consumer before confirming a meal orde $i$ in a catering business, the only realistic system would be computer-based. However, careful control of portion size is essential if the data held is to represent accurately the meal ordered. Fig. 1 outlines possible options in the construction of such a system.

There would be many permutations for accessing the information, but the businesses would need the quickest system which caused minimum delay in ordering. The type of food service employed would determine the most appropriate method. It is essential that 


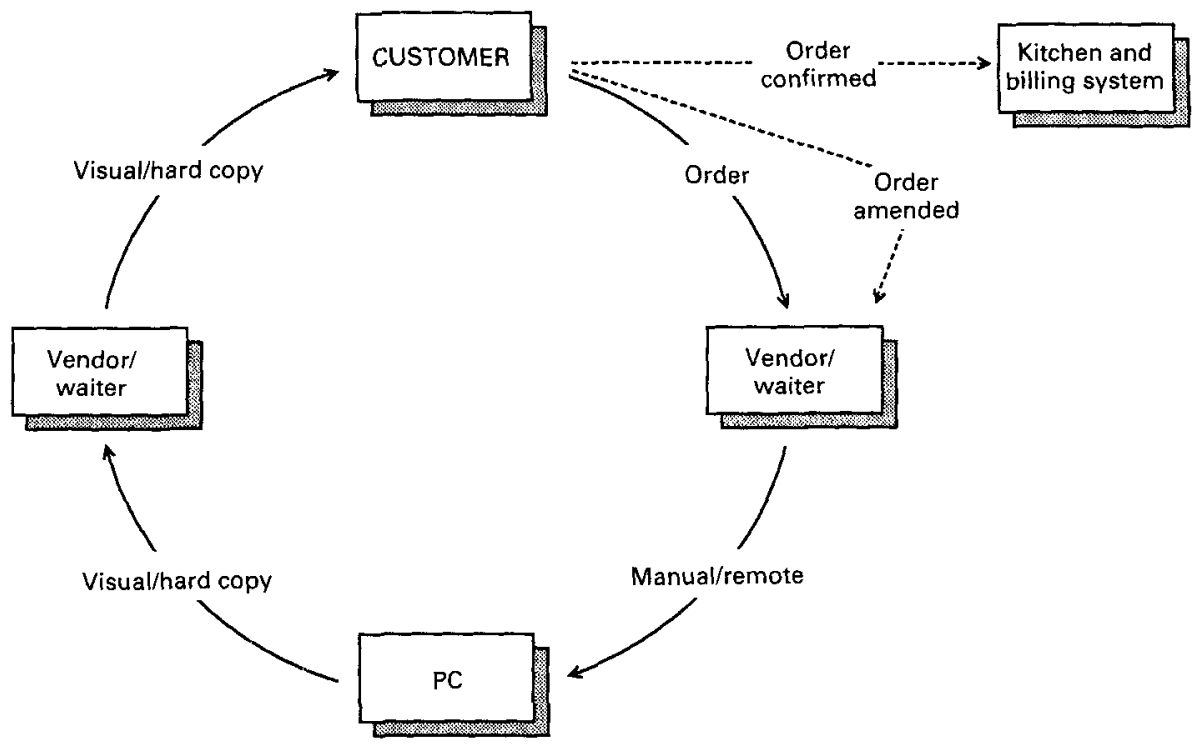

Fig. 1. Outline of a personal computer (PC)-based nutrition information system for menus carrying nutritional claims.

the normal food service system is disrupted as little as possible by the operation of such an information network, and it is with this requirement in mind that future developments should take place.

The eating-out sector is a key priority for encouraging healthy eating options, and the development of a flexible 'friendly' computerized system to provide nutrition information is the way forward to enhance the motivation of catering businesses to innovate successfully in the area of healthy eating.

\section{REFERENCES}

Advertising Association (1991). Marketing Pocket Book. London: Advertising Association.

Central Statistical Office (1991). Annual Abstract of Statistics. London: H.M. Stationery Office.

Department of Health (1991a). Dietary Reference Values for Food Energy and Nutrients for the UK. London: H.M. Stationery Office.

Department of Health (1991b). The Health of the Nation. London: H.M. Stationery Office.

Ministry of Agriculture, Fisheries and Food (1990). Household Food Consumption and Expenditure 1989. London: H.M. Stationery Office.

Ministry of Agriculture, Fisheries and Food (1991). The Food Advisory Committee's Review of Food Labelling - Table of Recommendations and the Government's Initial Response. London: H.M. Stationery Office.

Office of Population Census and Surveys (1990). The Dietary and Nutritional Survey of British Adults. Office of Population Census and Surveys. London: H.M. Stationery Office. 